\begin{tabular}{|c|c|c|c|c|c|c|c|c|c|c|c|}
\hline \multirow[b]{2}{*}{ Age (years) } & \multirow[b]{2}{*}{ No who died } & \multicolumn{5}{|c|}{ Diastolic blood pressure $(\mathrm{mm} \mathrm{Hg})$} & \multicolumn{5}{|c|}{ Systolic blood pressure $(\mathrm{mm} \mathrm{Hg})$} \\
\hline & & $\overline{<75}$ & $75-84$ & $85-94$ & $\geqslant 95$ & p Value ${ }^{\star}$ & $<130$ & $130-149$ & $150-169$ & $\geqslant 170$ & p Value \\
\hline \multicolumn{12}{|c|}{ Men } \\
\hline \multicolumn{12}{|l|}{ All cause: } \\
\hline 65 & $126 / 496$ & 0.96 & 0.61 & $1 \cdot 30$ & 1.50 & 0.01 & 0.50 & 0.87 & $1 \cdot 31$ & $1 \cdot 71$ & $<0.01$ \\
\hline 70 & $172 / 417$ & 0.78 & 0.95 & $1 \cdot 28$ & 1.01 & $0 \cdot 10$ & 0.77 & 0.94 & $1 \cdot 10$ & $1 \cdot 20$ & 0.05 \\
\hline$\geqslant 75$ & $150 / 246$ & $1 \cdot 29$ & $1 \cdot 02$ & 0.74 & 0.92 & 0.04 & $1 \cdot 18$ & 0.95 & 0.97 & 0.98 & 0.58 \\
\hline \multicolumn{12}{|c|}{ Cardiovascular: } \\
\hline 65 & $78 / 496$ & 0.90 & 0.49 & 1.45 & 1.62 & $<0.01$ & 0.43 & 0.84 & $1 \cdot 18$ & $2 \cdot 23$ & $<0.01$ \\
\hline 70 & $124 / 417$ & 0.72 & 0.92 & 1.33 & 1.09 & 0.05 & 0.63 & 0.82 & $1 \cdot 29$ & $1 \cdot 25$ & 0.01 \\
\hline$\geqslant 75$ & $118 / 246$ & $1 \cdot 36$ & 1.05 & 0.72 & 0.81 & 0.02 & $1 \cdot 28$ & 0.91 & 0.96 & 0.97 & 0.46 \\
\hline \multicolumn{12}{|c|}{ Women } \\
\hline \multicolumn{12}{|l|}{ All cause: } \\
\hline 65 & $83 / 515$ & 0.83 & 0.82 & $1 \cdot 36$ & $1 \cdot 19$ & $0 \cdot 10$ & 0.96 & 0.76 & 1.46 & $1 \cdot 22$ & $0 \cdot 19$ \\
\hline 70 & $84 / 386$ & 1.06 & 1.01 & 0.82 & $1 \cdot 27$ & 0.99 & 0.59 & 0.88 & $1 \cdot 23$ & $1 \cdot 37$ & 0.01 \\
\hline$\geqslant 75$ & $87 / 208$ & 0.79 & 0.95 & $1 \cdot 22$ & $1 \cdot 14$ & $0 \cdot 19$ & 0.74 & $0 \cdot 76$ & $1 \cdot 13$ & $1 \cdot 21$ & 0.08 \\
\hline \multicolumn{12}{|c|}{ Cardiovascular: } \\
\hline 65 & $42 / 515$ & 0.58 & 0.68 & 1.54 & $1 \cdot 76$ & 0.01 & 0.68 & $0 \cdot 78$ & $1 \cdot 77$ & 1.44 & 0.03 \\
\hline 70 & $43 / 386$ & 0.69 & $1 \cdot 25$ & 0.92 & 1.06 & 0.70 & 0.58 & 0.79 & $1 \cdot 37$ & $1 \cdot 34$ & 0.05 \\
\hline$\geqslant 75$ & $64 / 208$ & 0.89 & 0.89 & $1 \cdot 13$ & $1 \cdot 24$ & 0.33 & 0.88 & $0 \cdot 71$ & 0.97 & $1 \cdot 35$ & 0.09 \\
\hline
\end{tabular}

${ }^{\star} \chi^{2}$ Test for trend, $1 \mathrm{df}$.

from cardiovascular events suggest that much of the survival benefit was due to lower cardiovascular mortality. Our failure to find this paradoxical relation in women could be explained by a later onset of cardiovascular disease in women. ${ }^{5}$ The higher incidence and earlier onset of cardiovascular disease in Finland compared with the United States could also account for these contrasting results.

The positive relation between survival and diastolic blood pressure shown in men aged $\geqslant 75$ directly contrasts with the continuous negative relation between diastolic blood pressure and survival reported in younger people and in younger men and all women in our cohort. These results await explanation, and suggest a need to re-evaluate strategies for managing high blood pressure in very old patients.

This study was supported by grant NIADDKD AM31801.

1 Mattilea K, Haavisto M, Rajala S, Heikinhiemo R. Blood pressure and five year survival in the very old. BrMed f 1988;296:887-9.

2 Luepker RV. Coronary risk factor modification in the elderly coronary patient. Geriatric Cardiovascular Medicine 1988;1:115-21.

3 Kirkendall WM. Treatment of hypertension in the elderly. Am 7 Cardiol 1986; 57:63-68C.

4 Kannel WB. Prevalence, incidence, and hazards of hypertension in the elderly. Am Heart 7 1986;112:1362-3.

5 Thom TJ. Cardiovascular disease mortality among United States women. In: Eaker ED, Packard B, Wenger NK, Clarkson TB, Tyroler HA, eds. Coronary heart disease in women. New York: Haymarket Doyma, 1987:33-41.

(Accepted 3 March 1989)

\section{Insulin requirements of diabetic women who breast feed}

\author{
H Alban Davies, J D A Clark, K J Dalton, \\ O M Edwards
}

Department of Medicine, Addenbrooke's Hospital, Cambridge CB2 2QQ H Alban Davies, MRCP, senior registrar in medicine J D A Clark, MRCP, research fellow

O M Edwards, FRCP, consultant physician

Perinatal Research Unit, Rosie Maternity Hospital, University of Cambridge, Cambridge CB2 $2 Q Q$ $\mathrm{K} J$ Dalton, MRCOG, honorary consultant obstetrician

Correspondence to: $\mathrm{Dr}$ H Alban Davies, West Hill Hospital, Dartford, Kent DA1 2HF.

BrMed f 1989;298:1357-8
Diabetic women are advised to resume the dose of insulin that they took before pregnancy within one week after giving birth, whether they intend to breast feed or not, ${ }^{1}$ despite reports that breast feeding decreases insulin requirements. ${ }^{2}$ This ambivalence is due to lack of information about the effect of breast feeding on insulin requirements and the belief that it is difficult for mothers with diabetes to breast feed. ${ }^{23} \mathrm{We}$ describe the changes in insulin dose and diabetic control in diabetic women up to six weeks after delivery.

\section{Patients, methods, and results}

We studied 24 consecutive pregnancies in 21 insulin dependent diabetic women (three women had a second pregnancy during the study period). Breast feeding was established after 18 pregnancies and continued in 16 cases until the visit to the postnatal clinic six weeks later. Patients were initially advised to take the same dose of insulin as that taken before pregnancy. Five of those breast feeding, however, had moderately severe hypoglycaemic reactions while in the ward. Subsequently, insulin doses were reduced below the prepregnancy dose immediately after delivery and then adjusted according to blood glucose concentrations. The reduction in the insulin dose one week after delivery was 11.6 units ( $95 \%$ confidence interval 8.9 to 14.3 units, $p<0.001)$ in the women who were breast feeding compared with $5 \cdot 2$ units $(1 \cdot 1$ to $9 \cdot 3$ units, NS $)$ in those who were bottle feeding. The table shows the doses post partum and at the visit to the postnatal clinic. The reduction in the insulin dose post partum, but not that at the postnatal clinic, was significantly greater in those who were breast feeding than in those who were bottle feeding $(p=0 \cdot 03)$. Carbohydrate intake was not assessed accurately, but 10 of those breast feeding and one who bottle fed reported an increased intake after delivery.

The average reduction in the insulin dose post partum was 11.1 units $(8.3$ to 13.9 units) in the 18 women who delivered vaginally and 6.8 units $(1.7$ to 11.9 units) in the six who were delivered by caesarean section (intergroup difference, NS).

\section{Comment}

After delivery breast feeding women needed to reduce their insulin dose by $27 \%$ of their prepregnancy

Mean (SD) glycated haemoglobin and blood glucose concentrations and insulin doses during pregnancy, one week post partum, and at visit to postnatal clinic

\begin{tabular}{|c|c|c|c|c|c|c|c|}
\hline & \multicolumn{2}{|c|}{ Glycated haemoglobin (\%) } & \multirow{2}{*}{$\begin{array}{l}\text { Blood glucose } \\
\text { post partum } \\
(\mathrm{mmol} / \mathrm{l})\end{array}$} & \multicolumn{4}{|c|}{ Insulin dose (units) } \\
\hline & $\begin{array}{l}\text { At end of } \\
\text { pregnancy }\end{array}$ & $\begin{array}{l}\text { At postnatal } \\
\text { clinic }\end{array}$ & & $\begin{array}{l}\text { In early } \\
\text { pregnancy }\end{array}$ & $\begin{array}{l}\text { At end of } \\
\text { pregnancy }\end{array}$ & Post partum & $\begin{array}{l}\text { At postnatal } \\
\text { clinic }\end{array}$ \\
\hline $\begin{array}{l}\text { Breast feeding women } \\
\text { Bottle feeding women }\end{array}$ & $\begin{array}{l}6 \cdot 3(0 \cdot 7) \\
5 \cdot 9(0 \cdot 5)\end{array}$ & $\begin{array}{l}7 \cdot 6(1 \cdot 5) \\
6 \cdot 9(0 \cdot 3)\end{array}$ & $\begin{array}{l}6 \cdot 5(1 \cdot 8) \\
8 \cdot 8(3 \cdot 4)\end{array}$ & $\begin{array}{l}44(15) \\
46(10)\end{array}$ & $\begin{array}{l}96(36) \\
72(8)\end{array}$ & $\begin{array}{l}33(13) \\
41(10)\end{array}$ & $\begin{array}{l}37(13) \\
46(12)\end{array}$ \\
\hline
\end{tabular}


dose to avoid hypoglycaemic reactions. This is important because three quarters of our patients breast fed and two thirds continued to do so for at least six weeks. A similar proportion breast fed for six weeks in another study, ${ }^{3}$ and we believe that breast feeding should no longer be considered difficult for diabetics.

The control of blood glucose concentrations in the breast feeding women was good despite the reduced insulin dose and an increased carbohydrate intake by more than half of them. The average postnatal blood glucose concentration in those who bottle fed was higher than that in the breast feeding patients despite smaller dose reductions and an increased carbohydrate intake in only one. The reduced insulin requirements in the breast feeding women were unlikely to be due to the reduced responsiveness of growth hormone to insulin post partum as growth hormone concentrations do not depend on the method of feeding. ${ }^{4}$ Caesarean section may lead to a temporary fall in insulin requirements, ${ }^{5}$ but this was not the case in our study. We attribute the difference in insulin requirements to breast feeding; the carbohydrate supplements were unlikely to replace the lactose in milk.
Whichelow and Doddridge did not report insulin doses immediately post partum but found similar doses in breast feeding and bottle feeding women six weeks after delivery. ${ }^{3}$ Their patients increased their carbohydrate intake by $50 \mathrm{~g}$ while breast feeding, a supplement that was probably greater than that of our group. We advise that women who intend to breast feed should reduce their insulin by one quarter of their prepregnancy dose. They should also supplement their carbohydrate intake but may still require a reduction of insulin until after the postnatal visit. Those who bottle feed can resume the dose they took early in pregnancy.

1 Hare JW. Pregnancy and diabetes. In: Marble A, Krall LP, Bradley RF, Christlieb AR, Soeldner JS, eds. Joslin's diabetes mellitus. 12th ed. Philadelphia: Lea and Febiger, 1985:708.

2 Lawrence RA. Breast-feeding, a guide for the medical profession. London: C V Mosby, 1980.

Whichelow MJ, Doddridge MC. Lactation in diabetic women. Br Med f 1983;287:649-50.

4 Muntz DH, Stock R, Finster JL, Taylor AL. The effect of normal and diabetic pregnancies on growth hormone response to hypoglycemia. Metabolism pregnancies on

5 Lev-Ran A. Sharp temporary drop in insulin requirement after cesarean section in diabetic patients. Am f Obstet Gynecol 1974;120:905-8.

(Accepted 8 March 1989)

\section{Phaeochromocytoma with associated somatostatin production}

\author{
A H Morice, J S Price, M J Ashby, M J Brown
}

Clinical Pharmacology Unit, Addenbrooke's Hospital, Cambridge CB2 2QQ

A H Morice, MD, clinical lecturer

J S Price, MB, British Hear Foundation junior research fellow

M J Ashby, BSC, chief technician

M J Brown, MD, professor of clinical pharmacology

Correspondence to: $\mathrm{Dr}$ Morice.

BrMed f 1989;298:1358-9 of somatostatin by the tumour.

\section{Case report}

Phaeochromocytomas secrete large quantities of catecholamines into the circulation, and sustained hypertension is usually present at diagnosis. The tumour may also produce other neurotransmitters that have systemic effects such as vasoactive intestinal peptide, neurotensin, and neuropeptide $\mathrm{Y}$. We report on a patient with a phaeochromocytoma in whom biochemical confirmation of the diagnosis was delayed because resting concentrations of catecholamines were normal, possibly because of the associated production

A 40 year old general practitioner developed a sudden severe occipital headache while out jogging. It lasted four hours and was associated with anxiety, palpitations, tremor, nausea, and vomiting. Over the next three weeks he had up to three similar episodes a day and noticed pallor during them. His blood pressure during an episode was $160 / 90 \mathrm{~mm} \mathrm{Hg}$ compared with $120 / 80 \mathrm{~mm} \mathrm{Hg}$ between episodes.

He diagnosed a phaeochromocytoma but repeated estimations of urinary vanillylmandelic acid excretion over 24 hours were normal apart from one of $58 \mu \mathrm{mol} /$ $24 \mathrm{~h}$ (normal range 12-44) on the day of a severe episode. Abdominal computed tomography showed a small nodule in the right adrenal gland but scanning with radiolabelled $m$-iodobenzyl guanidine failed to confirm that it contained chromaffin tissue. Because of the conflicting biochemical and radiological results he was referred for provocation testing. The results of a physical examination were normal, his blood pressure was $140 / 90 \mathrm{~mm} \mathrm{Hg}$, and he showed no signs of sustained hypertension. He had had postprandial regurgitation for one year and so a profile of gut hormones was requested.

His basal catecholamine concentrations were within the normal range for radioenzymatic assay (noradrenaline $1.46 \mathrm{nmol} / \mathrm{l}$, range $1 \cdot 18-4 \cdot 72$; adrenaline $136 \mathrm{pmol} / \mathrm{l}$

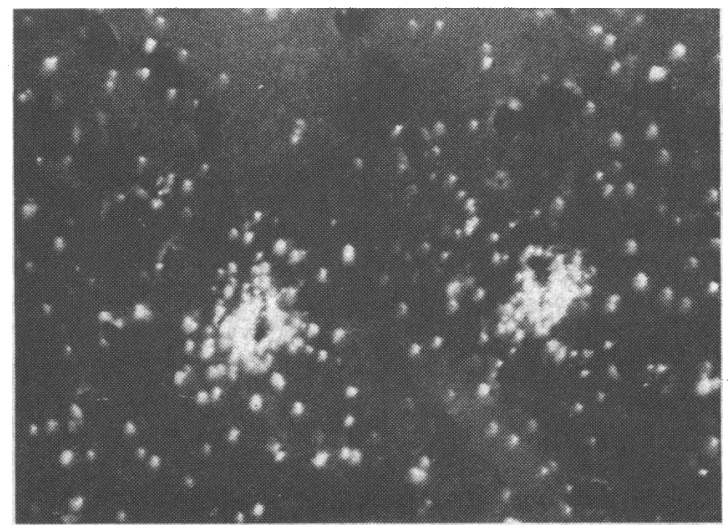

In situ hybridisation of synthetic 36 base oligonucleotide complementary to somatostatin messenger $R N A$ radio labelled with ${ }^{35} S$-deoxycytidine triphosphate. Fixed sections of phaeochromocytoma were incubated for one hour at $37^{\circ} \mathrm{C}$ with $50 \mu \mathrm{l}$ probe $(18 \mu \mathrm{M}), 50 \%$ formamide, $0 \cdot 3 \mathrm{M}$ sodium chloride, $0.03 \mathrm{M}$ sodium citrate, Denhardt's solution, salmon sperm DNA $0.25 \mathrm{mg} / \mathrm{ml}$, 5\% dextran sulphate, and $14 \mathrm{mM} \mathrm{2-}$ mercaptoethanol. Washed sections were dipped in Ilford nuclear emulsion and developed after 10 days. Dense collections of silver grains over cytoplasm of cells identifies those that contain somatostatin messenger RNA

range 110-440.' Provocation testing with glucagon $1 \mathrm{mg}$ intravenously produced no change in plasma noradrenaline concentration and the expected physiological increase in plasma adrenaline concentration. Selective venous sampling was undertaken, and catecholamine concentrations were normal at all 22 sites sampled. Plasma obtained during acute episodes did, however, contain raised catecholamine concentrations (mean values: noradrenaline $13.30 \mathrm{nmol} / \mathrm{l}$, adrenaline $1965 \mathrm{pmol} / \mathrm{l}$ ), and further scanning with radiolabelled $m$-iodobenzylguanidine with digital subtraction of the hepatic image showed uptake of label in the right adrenal gland.

The profile of gut hormones showed an increased plasma concentration of somatostatin of $147 \mathrm{pmol} / \mathrm{l}$ (normal $<100$ ) but normal concentrations of gastrin $(15 \mathrm{pmol} / \mathrm{l})$, glucagon $(11 \mathrm{pmol} / \mathrm{l})$, neurotensin $(28$ $\mathrm{pmol} / \mathrm{l})$, and vasoactive intestinal peptide $(4 \mathrm{pmol} / \mathrm{l})$.

At operation a phaeochromocytoma measuring 1.5 $\mathrm{cm}$ was removed from the right adrenal gland. In situ hybridisation of sections of the tumour showed cells with positive binding for an oligonucleotide complementary to somatostatin messenger RNA (figure). No such binding was detected in sections from an unrelated 